\title{
THE CONCEPT OF IMPLEMENTING THE ACTIVITY-BASED COSTING IN MULTI- ASSORTMENT MANUFACTURING ENTERPRISE - CASE STUDY (PART 2)
}

\author{
Daria MOSKWA-BĘCZKOWSKA \\ Kielce University of Technology, The Chair of Economic and Finance, Poland; dariam@tu.kielce.pl, \\ ORCID: 0000-0003-2165-6829
}

Purpose: As mentioned in the first part of the article, its main objective is to develop and present a concept for the implementation of activity-based costing in a company dealing with multi-assortment production of bookbinding machinery.

Design/methodology/approach: The main research method used is a case study of the implementation of activity-based costing in a selected multi-assortment production company. The concept of an original model of implementation of activity-based costing in the analyzed company as well as the benefits resulting from this implementation are presented in this article. Findings: The carried-out research indicates that the calculation of cost according to the concept of activity-based costing is more useful for effective cost management than traditional methods. After the development and presentation of the model of the analyzed costing method, the board of directors of the examined company began seriously considering the implementation of this method within their business unit.

Research limitations/implications: The main barrier in the conducted research was the lack of conviction on the part of the company about the advantages of the presented unit cost calculation method and its usefulness for effective cost management within the company.

Originality/value: The article is an example of the practical application of activity-based costing in multi-assortment production. Its content is directed both to persons dealing with these matters from the theoretical perspective, as well as company owners and heads of controlling or production departments.

Keywords: activity-based costing, implementation of, multi-assortment production.

Category of the paper: research paper, case study.

\section{Introduction}

According to the considerations presented in the article entitled The concept of implementing the activity-based costing in multi-assortment manufacturing enterprise - case study, traditional costing methods, including above all full costing, do not meet the information 
requirements of their users with regards to costs. Therefore, some companies decide to change their existing costing systems to other, more advanced systems. One such tool is activity-based costing, whose conceptual assumptions as well as calculation procedures are presented in the above-mentioned article.

This article presents an original model of implementation of activity-based costing in a multi-assortment production company. Therefore, the aim here is to present the necessary assumptions and calculation procedures for its implementation. All theoretical considerations were supported using numerical examples. To maintain the confidentiality of the examined company, for the purposes of this case study, it shall hereinafter be referred to as company $\mathrm{X}$.

\section{Implementation of activity-based costing in a company — case study}

The subject of the study is a production company from Świętokrzyskie voivodeship, which deals with the production of bookbinding and printing machinery. The company is characterized by a multi-assortment production, with 17 assortment groups in its offer portfolio, almost all of which additionally feature various models of a given product. In total, the company distributes around 130 models of machinery and equipment, including 8 models produced in-house. Paper cutters are the company's core products. Nearly $80 \%$ of the products are exported abroad, mainly to Western Europe, the Middle East and North America. Moreover, the company has its own warranty and post-warranty service for machines and a warehouse for spare parts for the offered products. The examined company has a total of 34 employees. Table 1 shows the detailed employment structure in the company.

Table 1.

Employment structure in Company $X$

\begin{tabular}{|c|l|c|}
\hline No. & \multicolumn{1}{|c|}{ Organizational unit } & Number of employees \\
\hline 1. & Management Board & 2 \\
\hline 2. & Accounting Department & 2 \\
\hline 3. & Sales Department & 3 \\
\hline 4. & Production Department & 22 \\
\hline 5. & Quality Control Department & 1 \\
\hline 6. & Machine Service and Installation Department & 3 \\
\hline 7. & Warehouse & 1 \\
\hline
\end{tabular}

Source: Own elaboration.

Accounting at Company $\mathrm{X}$ is carried out on the basis of the provisions of the Polish Accounting Act of 29 September 1994 and as the net revenues from the sale of products for the previous financial years amounted to more than EUR 2 million, the company employs so-called comprehensive bookkeeping (Act, 1994). The company's costs and revenues are recorded both 
by type and by function, i.e. on accounts of group 4 and $5^{1}$. Cost recording occurs on a number of analytical levels. The production cost of a single machine is calculated in accordance with the rules specified in the Act, i.e. as a full cost of manufacturing, which means that the company keeps cost records divided into direct and indirect costs. The latter represents nearly $70 \%$ of all costs incurred within the company.

The main problem of the company in question is finding such a method of unit cost calculation, which will allow detailed presentation of the level and structure of costs of the manufacturing process. For this reason, the company decided to implement a method of unit cost calculation that would make the calculations carried out thus far credible.

Further considerations will feature the calculations of manufacturing costs of three core products of Company X, namely: paper cutter G73, paper cutter G52 and paper cutter G52H, so-called cost calculation objects, which shall be carried out using cost calculation procedures according to the concept of activity-based costing. In the example, the products are defined as Product X, Product Y and Product Z, respectively. The calculation of unit costs of these products will be carried out according to the individual stages of the activity-based costing implementation procedure, i.e.:

1. identifying the relevant processes and activities taking place within the company,

2. determining the resource structure type of the company and the value of resource consumption,

3. defining resource cost drivers,

4. determining costs of the distinguished activities,

5. defining activity cost drivers,

6. settlement of indirect costs of individual activities into cost objects.

\subsection{Stage 1. Identifying the relevant processes and activities taking place within Company X}

The core element of the implementation of the analyzed costing method in each company is the identification of processes and activities. It is repeatedly stressed in the literature on the subject that this is the most important and, at the same time, the most difficult stage of implementation of activity-based costing. As mentioned, it is the processes and activities that are the direct cause of cost generation, so their precise identification determines the success of the entire calculation procedure. The level of costs in a company is therefore directly influenced by the number of activities and their scope. The implementation team should therefore select the level of specificity in the definition of activities in such a manner that, on the one hand, all activities that have an impact on the level of costs are taken into account and, on the other hand, that their number is not too large so as not to make the functioning of the costing of activities overly complex and costly. The Pareto rule should be followed here, which assumes that $20 \%$ of all activities generate as much as $80 \%$ of costs incurred within the company.

\footnotetext{
${ }^{1}$ Given the objective of this article, only information concerning the costs incurred in this company will be presented.
} 
In Company X, no detailed identification of the implemented processes and activities was carried out. The Management Board of the examined company was not fully convinced of the validity of the implementation of the presented method and did not want to undertake timeconsuming implementation work without knowing the advantages of this costing method beforehand. Therefore, an example - partly taken from the literature on the subject of a glossary of activities performed in a production company, adapted for the purpose of this calculation, was used. Table 2 presents a list of exemplary actions implemented in Company X.

Table 2.

Glossary of activities of Company $X$

\begin{tabular}{|l|l|}
\hline \multicolumn{1}{|c|}{ Name of activity } & \multicolumn{1}{c|}{ Activity cost driver } \\
\hline Technical preparation of production & Time of technical preparation of production \\
\hline Production planning & Number of production orders \\
\hline Machinery setup & Number of production batches \\
\hline Production operation & Operation time in working hours \\
\hline Warehouse management & Number of components \\
\hline In-house transport & Number of material transfers \\
\hline Quality control & Number of tests \\
\hline Change in technical conditions of production & Number of changes \\
\hline Computerized production control & Number of production runs \\
\hline Service and consulting & Number of services provided \\
\hline Installation of machines at customers' premises & Number of installations at customer's premises \\
\hline
\end{tabular}

Source: Own elaboration.

According to the information presented in the table above, apart from the identified activities, the second-degree statistical key figures were immediately defined, which are referred to as activity cost drivers in activity-based costing. It makes it possible to settle the costs of particular activities into cost objects. Although in the procedure of implementation of this costing method it is the subject of Stage 5, when identifying individual activities carried out in Company $\mathrm{X}$, the corresponding drivers were immediately defined.

\subsection{Stage 2. Determining the resource structure type of the company and the value of resource consumption. Stage 3. Definition of resource cost drivers}

In Stage 2 of the implementation of the activity-based costing it is necessary to identify the resource structure type used in the implementation of individual activities and to determine the value of their consumption. Cost accounting records and all other documents, such as depreciation plans or evidence of material consumption, are extremely helpful in this case. In the examined company, the direct cost accounting records are kept in quite a detailed manner, the chart of accounts of group 4 is kept on a number of analytical levels. Indirect costs, on the other hand, are treated as a single category and settled to object costs in an appropriate proportion. And it is the structure type of indirect costs that is crucial for the valuation of manufactured products and services offered. In activity-based costing, the level of generic cost is the actual level of consumption of a given type of resource assigned to an adequate activity. 
The main resources of the analyzed company include: employees, buildings, machinery and equipment used in production, materials and components, means of transport, office equipment and utilities. Their identification allows moving to the subsequent stage of the procedure of implementing the concept of activity-based costing. In Stage 3, the value of resources consumed for activities should be accounted for, for this purpose it is necessary to define the so-called resource cost driver for each resource. In the literature these are defined as measures of the amount of resources used or consumed in the performance of individual activities. Table 3 presents the proposed cost drivers for the identified resources.

Table 3.

Resource cost drivers in Company $X$

\begin{tabular}{|l|l|}
\hline \multicolumn{1}{|c|}{ Name of resource } & \multicolumn{1}{c|}{ Resource cost driver } \\
\hline Employees & Number of employees \\
\hline Buildings & Area in $\mathrm{m}^{2}$ \\
\hline Machinery and equipment & Machine-hours \\
\hline Materials and components & Amount of materials used \\
\hline Modes of transportation & Number of km driven \\
\hline Office equipment & Machine-hours \\
\hline Utilities & Volume of consumption \\
\hline
\end{tabular}

Source: Own elaboration.

The next stage is to settle - by means of defined drivers - the value of resources used for activities. This settlement in schematic terms is significantly facilitated by the resourcesactivities matrix, however, due to the limitation regarding the size of this article it will not be presented here.

The final result of the above-mentioned settlement stages are the so-called activity cost pools, which correspond to the amount of costs generated by individual activities.

\subsection{Stage 4. Determining costs of the distinguished activities}

Stage 4 is aimed at determining the cost of all activities identified in the company. The relevant values for Company $\mathrm{X}$ are presented in Table 4.

Table 4.

Activity cost pools in Company X

\begin{tabular}{|l|r|}
\hline \multicolumn{1}{|c|}{ Name of activity } & \multicolumn{1}{c|}{ Activity cost pools } \\
\hline Technical preparation of production & $1,200.00$ \\
\hline Production planning & $3,000.00$ \\
\hline Machinery setup & $1,000.00$ \\
\hline Production operation & $34,600.00$ \\
\hline Warehouse management & $1,000.00$ \\
\hline In-house transport & 762.00 \\
\hline Quality control & $2,500.00$ \\
\hline Change in technical conditions of production & $1,800.00$ \\
\hline Computerized production control & $3,000.00$ \\
\hline Service and consulting & $1,200.00$ \\
\hline Installation of machines at customers' premises & $2,350.00$ \\
\hline \multicolumn{2}{c}{ Total indirect costs } \\
\hline
\end{tabular}

Source: Own elaboration. 


\subsection{Stage 5. Defining activity cost drivers}

As mentioned, Stage 5 was carried out as one of the first, which had no impact on the unit cost calculation procedure. Once the activity cost drivers have been defined, the individual cost objects required for specific activities should be determined. For this purpose - as in Stage 3 - the activities-cost objects matrix is created, but due to the limitation regarding the size of this article it will not be presented here, as with the previous one. The result of the performed calculation stage is an answer to the question about the value of costs per unit of activity the results obtained are presented in Table 5.

Table 5.

Unit costs of activities implemented in Company X

\begin{tabular}{|c|c|c|c|c|}
\hline Name of activity & Activity costs driver & $\begin{array}{c}\text { Total } \\
\text { activity costs }\end{array}$ & $\begin{array}{r}\text { Size of } \\
\text { activity }\end{array}$ & $\begin{array}{c}\text { Unit cost of } \\
\text { activity }\end{array}$ \\
\hline Technical preparation of production & $\begin{array}{l}\text { Time of technical preparation of } \\
\text { production }\end{array}$ & $1,200.00$ & 5 & 240.00 \\
\hline Production planning & Number of production orders & $3,000.00$ & 5 & 600.00 \\
\hline Machinery setup & Number of production batches & $1,000.00$ & 5 & 200.00 \\
\hline Production operation & Operation time in working hours & $34,600.00$ & 40 & 865.00 \\
\hline Warehouse management & Number of components & $1,000.00$ & 20 & 50.00 \\
\hline In-house transport & Number of material transfers & 762.00 & 3 & 254.00 \\
\hline Quality control & Number of tests & $2,500.00$ & 5 & 500.00 \\
\hline $\begin{array}{l}\text { Change in technical conditions of } \\
\text { production }\end{array}$ & Number of changes & $1,800.00$ & 3 & 600.00 \\
\hline Computerized production control & Number of production runs & $3,000.00$ & 5 & 600.00 \\
\hline Service and consulting & Number of services provided & $1,200.00$ & 10 & 120.00 \\
\hline $\begin{array}{l}\text { Installation of machines at } \\
\text { customers' premises }\end{array}$ & $\begin{array}{l}\text { Number of installations at } \\
\text { customer's premises }\end{array}$ & $2,350.00$ & 5 & 470.00 \\
\hline Total indirect costs & & $52,412.00$ & $\mathrm{X}$ & $\mathrm{X}$ \\
\hline
\end{tabular}

Source: Own elaboration.

\subsection{Stage 6. Settlement of indirect costs of individual activities into cost objects}

The last stage of the implementation of the activity-based costing in Company $\mathrm{X}$ is the settlement of activity costs - listed in Table 4 - into established cost objects, i.e. products X, $\mathrm{Y}$ and $\mathrm{Z}$. The relevant calculations are presented in Tables 6, 7 and 8.

Table 6.

Indirect costs for Product X

\begin{tabular}{|l|c|c|c|c|c|}
\hline \multicolumn{1}{|c|}{ Name of activity } & $\begin{array}{c}\text { Activity size } \\
\text { for Product X }\end{array}$ & $\begin{array}{c}\text { Unit cost } \\
\text { of activity }\end{array}$ & $\begin{array}{c}\text { Total activity costs } \\
\text { for Product X }\end{array}$ & $\begin{array}{c}\text { Production } \\
\text { volume }\end{array}$ & $\begin{array}{c}\text { Unit indirect } \\
\text { costs }\end{array}$ \\
\hline $\begin{array}{l}\text { Technical preparation of } \\
\text { production }\end{array}$ & 3 & 240.00 & 720.00 & 10 & 72.00 \\
\hline Production planning & 3 & 600.00 & $1,800.00$ & 10 & 180.00 \\
\hline Machinery setup & 2 & 200.00 & 400.00 & 10 & 40.00 \\
\hline Production operation & 20 & 865.00 & $17,300.00$ & 10 & $1,730.00$ \\
\hline Warehouse management & 7 & 50.00 & 350.00 & 10 & 35.00 \\
\hline In-house transport & 1 & 254.00 & 254.00 & 10 & 25.40 \\
\hline Quality control & 2 & 500.00 & $1,000.00$ & 10 & 100.00 \\
\hline $\begin{array}{l}\text { Change in technical conditions } \\
\text { of production }\end{array}$ & 1 & 600.00 & 600.00 & 10 & 60.00 \\
\hline $\begin{array}{l}\text { Computerized production } \\
\text { control }\end{array}$ & 2 & 600.00 & $1,200.00$ & 10 & 120.00 \\
\hline
\end{tabular}


Cont. table 6.

\begin{tabular}{|l|c|c|c|c|c|}
\hline Service and consulting & 6 & 120.00 & 720.00 & 10 & 72.00 \\
\hline $\begin{array}{l}\text { Installation of machines at } \\
\text { customers' premises }\end{array}$ & 3 & 470.00 & $1,410.00$ & 10 & 141.10 \\
\hline Unit indirect costs
\end{tabular}

Source: Own elaboration.

Table 7.

Indirect costs for Product $Y$

\begin{tabular}{|l|c|c|c|c|c|}
\hline \multicolumn{1}{|c|}{ Name of activity } & $\begin{array}{c}\text { Activity size } \\
\text { for Product Y }\end{array}$ & $\begin{array}{c}\text { Unit cost } \\
\text { of activity }\end{array}$ & $\begin{array}{c}\text { Total activity costs } \\
\text { for Product Y }\end{array}$ & $\begin{array}{c}\text { Production } \\
\text { volume }\end{array}$ & $\begin{array}{c}\text { Unit indirect } \\
\text { costs }\end{array}$ \\
\hline $\begin{array}{l}\text { Technical preparation of } \\
\text { production }\end{array}$ & 1 & 240.00 & 240.00 & 15 & 16.00 \\
\hline Production planning & 1 & 600.00 & 600.00 & 15 & 40.00 \\
\hline Machinery setup & 2 & 200.00 & 400.00 & 15 & 26.67 \\
\hline Production operation & 15 & 865.00 & $12,975.00$ & 15 & 865.00 \\
\hline Warehouse management & 7 & 50.00 & 350.00 & 15 & 23.33 \\
\hline In-house transport & 1 & 254.00 & 254.00 & 15 & 16.93 \\
\hline Quality control & 2 & 500.00 & $1,000.00$ & 15 & 66.67 \\
\hline $\begin{array}{l}\text { Change in technical conditions } \\
\text { of production }\end{array}$ & 1 & 600.00 & 600.00 & 15 & 40.00 \\
\hline $\begin{array}{l}\text { Computerized production } \\
\text { control }\end{array}$ & 2 & 600.00 & $1,200.00$ & 15 & 80.00 \\
\hline Service and consulting & 2 & 120.00 & 240.00 & 15 & 16.00 \\
\hline $\begin{array}{l}\text { Installation of machines at } \\
\text { customers' premises }\end{array}$ & 1 & 470.00 & 470.00 & 15 & 31.33 \\
\hline Unit indirect costs & \multicolumn{2}{|c|}{} \\
\hline
\end{tabular}

Source: Own elaboration.

Table 8.

Indirect costs for Product $Z$

\begin{tabular}{|l|c|c|c|c|c|}
\hline \multicolumn{1}{|c|}{ Name of activity } & $\begin{array}{c}\text { Activity size } \\
\text { for Product Z }\end{array}$ & $\begin{array}{c}\text { Unit cost } \\
\text { of activity }\end{array}$ & $\begin{array}{c}\text { Total activity costs } \\
\text { for Product Z }\end{array}$ & $\begin{array}{c}\text { Production } \\
\text { volume }\end{array}$ & $\begin{array}{c}\text { Unit indirect } \\
\text { costs }\end{array}$ \\
\hline $\begin{array}{l}\text { Technical preparation of } \\
\text { production }\end{array}$ & 1 & 240 & 240 & 5 & 48.00 \\
\hline Production planning & 1 & 600 & 600 & 5 & 120.00 \\
\hline Machinery setup & 1 & 200 & 200 & 5 & 40.00 \\
\hline Production operation & 5 & 865 & 4325 & 5 & 865.00 \\
\hline Warehouse management & 6 & 50 & 300 & 5 & 60.00 \\
\hline In-house transport & 1 & 254 & 254 & 5 & 508.00 \\
\hline Quality control & 1 & 500 & 500 & 5 & 100.00 \\
\hline $\begin{array}{l}\text { Change in technical conditions } \\
\text { of production }\end{array}$ & 1 & 600 & 600 & 5 & 120.00 \\
\hline $\begin{array}{l}\text { Computerized production } \\
\text { control }\end{array}$ & 1 & 600 & 600 & 5 & 120.00 \\
\hline Service and consulting & 2 & 120 & 240 & 5 & 48.00 \\
\hline $\begin{array}{l}\text { Installation of machines at } \\
\text { customers' premises }\end{array}$ & 1 & 470 & 470 & 5 & 94.00 \\
\hline Unit indirect costs & & & & $\mathbf{1 , 6 6 5 . 8 0}$ \\
\hline
\end{tabular}

Source: Own elaboration.

Tables 6, 7 and 8 present the calculation of the unit indirect costs for paper cutters manufactured by the examined company. In order to determine the total unit costs of products, it is also necessary to establish the unit direct costs, including the costs of consumption of material and renumeration of the production personnel. The examined company, as already mentioned, keeps detailed records of direct costs in the accounts of group 4. The data concerning these costs are shown in Table 9. 
Table 9.

Unit direct costs of products $X, Y, Z$

\begin{tabular}{|l|r|r|r|}
\hline \multirow{2}{*}{ Item } & \multicolumn{3}{c|}{ Finished products } \\
\cline { 2 - 4 } & \multicolumn{1}{|c|}{ X } & \multicolumn{1}{c|}{$\mathbf{Z}$} \\
\hline Direct materials & $35,000.00$ & $28,000.00$ & $25,000.00$ \\
\hline Direct wages & $50,000.00$ & $20,000.00$ & $11,000.00$ \\
\hline TOTAL & $\mathbf{8 5 , 0 0 0 . 0 0}$ & $\mathbf{4 8 , 0 0 0 . 0 0}$ & $\mathbf{3 6 , 0 0 0 . 0 0}$ \\
\hline Production volume & 10 & 15 & 5 \\
\hline Unit direct costs & $\mathbf{8 , 5 0 0 . 0 0}$ & $\mathbf{3 , 2 0 0 . 0 0}$ & $\mathbf{7 , 2 0 0 . 0 0}$ \\
\hline
\end{tabular}

Source: Own elaboration.

Having determined both unit direct costs (see table 9) and unit indirect costs (see tables 6, 7 and 8), it is possible to determine unit manufacturing costs of the analyzed finished products. The results of the performed calculations are presented in Table 10.

Table 10.

Unit manufacturing costs of products $X, Y$ and $Z$

\begin{tabular}{|l|r|r|r|}
\hline \multirow{2}{*}{\multicolumn{1}{c|}{ Item }} & \multicolumn{3}{c|}{ Finished products } \\
\cline { 2 - 4 } & \multicolumn{1}{c|}{ Y } & \multicolumn{1}{c|}{$\mathbf{Z}$} \\
\hline Unit direct costs & $8,500.00$ & $3,200.00$ & $7,200.00$ \\
\hline Unit indirect costs & $2,575.50$ & $1,221.93$ & $1,665.80$ \\
\hline TOTAL & $\mathbf{1 1 , 0 7 5 . 5 0}$ & $\mathbf{4 , 4 2 1 . 9 3}$ & $\mathbf{8 , 8 6 5 . 8 0}$ \\
\hline
\end{tabular}

Source: Own elaboration.

The data in Table 10 shows that the unit manufacturing costs of paper cutters determined according to the activity-based costing concept amounted to $11,075.50$ for the G73 model (Product X), 4,421.93 for the G52 model (Product Y) and 8,865.80 for the G52H model (Product Z).

The results obtained differ significantly from the value of these costs determined using the traditional costing method ${ }^{2}$, however, from the point of view of the analyzed company it was not the value of manufacturing costs that mattered but their scope and structure. It was important for the board of directors of Company $\mathrm{X}$ to obtain reliable information on costs from the costing system, in particular with regard to the level and structure of indirect costs. Recognizing the advantages of this concept, Company $\mathrm{X}$ also began to consider the possibility of extending the cost analysis to direct costs. Furthermore, it was clearly stated that activity-based costing is an excellent cost management tool, providing multifaceted opportunities for analysis and evaluation. According to the company, the costing method will no longer be considered as a mere management accounting tool and the information derived from it will cease to be used mainly for drawing up obligatory financial statements. Company $\mathrm{X}$ will finally gain an advanced cost management tool functioning in the area of operational and strategic management. In their opinion, the benefits from the implementation of activity-based costing are so great that the costs and the amount of work associated with the elaboration and implementation of this concept within the company become irrelevant.

\footnotetext{
${ }^{2}$ In view of the purpose of this article, which is to develop a concept for the implementation of activity-based costing in the analyzed company, as well as the size limitations of this article, the calculation of unit costs according to the traditional full costing will not be presented here.
} 


\section{Final thoughts}

Activity-based costing is an advanced method of unit cost calculation. Its implementation within a company enables conducting a broader analysis of the level and structure of the costs of manufacturing products, which makes the determination of their amount more reliable. In contrast to the traditional full costing method, numerous different statistical key figures can be used in activity-based costing, which makes the level of the calculated cost even more reliable. The presented advantages of the analyzed concept of cost calculation for the analyzed company - at the same time became the main arguments for switching from the costing system employed so far to activity-based costing. The new approach to the allocation of indirect costs in defined cost objects was of great significance here. The analyzed company, after having presented the results of the unit cost calculation for the manufacturing of their core products, began to seriously consider the implementation of activity-based costing at their plant.

\section{References}

1. Accounting Act of 29 September 1994 (Journal of Laws No. 121, item 591, as amended).

2. Dobija, M. (1995). Rachunkowość zarządcza. Warszawa: PWN.

3. Dobija, M. (1997). Rachunkowość zarzadcza i controlling. Warszawa: PWN.

4. Gabrusewicz, W., Kamela-Sowińska, A., Poetschke, H. (2002). Rachunkowość zarzadcza. Warszawa: PWE.

5. Kłosowski, M. (2013). Koszty procesów w rachunku kosztów działań. Polskie Towarzystwo Zarządzania Produkcją.

6. Moskwa-Bęczkowska, D. (2019). Efektywne zarządzanie kosztami publicznych szkót wyższych w Polsce. Kielce: Kielce University of Technology.

7. Nowak, E. (1996). Teoria kosztów w zarządzaniu przedsiębiorstwem. Warszawa: PWN.

8. Nowak, E., Piechota, R., Wierzbiński, M. (2004). Rachunek kosztów w zarządzaniu przedsiębiorstwem. Warszawa: PWE.

9. Nowak, E., Wierzbiński, M. (2010). Rachunek kosztów. Modele i zastosowania. Warszawa: PWE.

10. Raiborn, C.A., Kinney, M. R. (2010). Cost Accounting. The United States: South Western Educational Publishing.

11. Skarżyńska, A. (2012). Rachunek kosztów działań - nowe spojrzenie. Zagadnienia Ekonomiki Rolnej, No. 3. Warszawa. 
12. Sołtys, D. (2014). Rachunkowość zarządcza przedsiębiorstw. Rachunek kosztów. Wrocław: Wrocław University of Economics.

13. Świderska, G.K. (ed.) (2003). Rachunkowość zarzadcza i rachunek kosztów. Warszawa: Difin. 